University of Nebraska - Lincoln

DigitalCommons@University of Nebraska - Lincoln

Faculty Papers and Publications in Animal

Science

Animal Science Department

October 2003

\title{
Estimates of genetic parameters and selection strategies to improve the economic efficiency of postweaning growth in lambs
}

\author{
G. D. Snowder \\ USDA, ARS, U.S. Meat Animal Research Center \\ L. Dale Van Vleck \\ University of Nebraska-Lincoln, dvan-vleck1@unl.edu
}

Follow this and additional works at: https://digitalcommons.unl.edu/animalscifacpub

Part of the Animal Sciences Commons

Snowder, G. D. and Van Vleck, L. Dale, "Estimates of genetic parameters and selection strategies to improve the economic efficiency of postweaning growth in lambs" (2003). Faculty Papers and Publications in Animal Science. 196.

https://digitalcommons.unl.edu/animalscifacpub/196

This Article is brought to you for free and open access by the Animal Science Department at DigitalCommons@University of Nebraska - Lincoln. It has been accepted for inclusion in Faculty Papers and Publications in Animal Science by an authorized administrator of DigitalCommons@University of Nebraska - Lincoln. 


\title{
Estimates of genetic parameters and selection strategies to improve the economic efficiency of postweaning growth in lambs ${ }^{1}$
}

\author{
G. D. Snowder*2 and L. D. Van Vleck $\dagger$ \\ *USDA, ARS, U.S. Meat Animal Research Center, Clay Center, NE 68933 and \\ $\dagger$ USDA, ARS, U.S. Meat Animal Research Center, Lincoln, NE 68583
}

\begin{abstract}
The objectives of this study were to estimate (co)variance components for growth and feed efficiency measures, and to compare selection strategies to improve economic efficiency of gain. Variance components for pre- and postweaning growth, body weight, and measures of feed efficiency were estimated from data collected on 1,047 Targhee lambs over 7 yr. Approximately $21 \mathrm{~d}$ after weaning, lambs were group-fed for $4 \mathrm{wk}$, with ad libitum access to a diet of $37 \%$ whole barley grain and $63 \%$ pelleted alfalfa hay. Lambs were then individually fed for 6 wk. Lambs were then returned to group feeding for another 4 -wk period. The mean feed conversion ratio (gain/intake) for the individual feeding period was 0.11 . Mean postweaning $\mathrm{ADG}$ for the total 14-wk feeding period was $0.26 \mathrm{~kg}$. (Co)variance components were estimated from single- and two-trait animal models using REML. The selection strategies compared included direct selection, index selection, and restricted index selection. Estimates of (co)variances derived from single- and two-trait models were similar,
\end{abstract}

except for mid-test body weight. Preweaning growth had a low heritability estimate $(0.03 \pm 0.04)$ compared with postweaning growth measures (0.25 to 0.39$)$, but all measures of growth were highly correlated $\left(\mathrm{r}^{2}>\right.$ 0.98). Heritability estimates of measures of gain efficiency were variable (total feed intake $=0.39$; feed conversion ratio $=0.26$; residual feed intake $=0.26$ ). Total feed intake was strongly correlated genetically with feed conversion ratio (0.79) and residual feed intake (0.77). The estimate of genetic correlation between feed conversion ratio and residual feed intake was low (0.23). Comparison of selection strategies showed the superiority of index selection (ADG, total feed, body weight) for economic improvement compared with other strategies. Economic response to direct selection for ADG was at least twice that for direct selection for feed conversion ratio or against total feed intake, and that for restricted indices (selecting against residual feed, while holding body weight and/or gain constant). Selection for ADG may be a practical approach for indirectly improving efficiency of gain in lambs.

Key Words: Growth, Residual Feed Intake, Selection, Sheep

(C2003 American Society of Animal Science. All rights reserved.

J. Anim. Sci. 2003. 81:2704-2713

\section{Introduction}

An increase in profitability of lamb production is dependent on reducing input costs and/or increasing production output. Because a large number of lambs in the United States are conditioned for slaughter in feedlots, cost of feed is an important economic input factor whereas lamb growth rate is an important economic output factor. Any reduction in feed intake or increase in feed efficiency without compromising growth rate or carcass quality can have a significant positive economic

\footnotetext{
${ }^{1}$ Mention of a trade name does not constitute an implied warranty by USDA or the authors.

${ }^{2}$ Correspondence: P.O. Box 166 (phone: 402-762-4167; fax: 402762-4173; E-mail: snowder@email.marc.usda.gov).

Received January 29, 2003.

Accepted August 8, 2003.
}

impact on lamb production. Genetic improvement of these traits can be increased with knowledge of their genetic parameters. Although genetic parameters for pre- and postweaning growth rate have been extensively investigated in lambs, only a limited number of genetic parameters for feed efficiency traits in lambs have been reported.

Direct selection for feed efficiency traits in sheep may not be an appropriate method for genetic improvement due to the high costs associated with measuring feed intake. If a correlated trait that is easier and more economical to measure can be identified, indirect selection to improve feed efficiency would be a more practical approach. The genetic correlation between feed efficiency traits and growth rate has been reported to be moderately high in cattle, swine, chickens, and mice (reviewed by Eisen, 1977). Therefore, the primary objective of this study was to estimate (co)variances for feed efficiency traits, including residual feed intake, and 
Table 1. Number of lambs and unadjusted means for age, live weight, ADG, and feed conversion ratio of Targhee lambs

\begin{tabular}{|c|c|c|c|c|c|c|c|c|c|c|}
\hline Year & $\begin{array}{l}\text { No. } \\
\text { lambs }\end{array}$ & $\begin{array}{c}\text { Age at } \\
\text { weaning, } d\end{array}$ & $\begin{array}{c}\text { Wt at } \\
\text { weaning, } \mathrm{kg}\end{array}$ & $\begin{array}{l}\text { Preweaning } \\
\text { ADG, kg }\end{array}$ & $\begin{array}{l}\text { Age on } \\
\text { test, d }\end{array}$ & $\begin{array}{l}\text { Wt on } \\
\text { test, kg }\end{array}$ & $\begin{array}{l}\text { Wt off } \\
\text { test, } \mathrm{kg}\end{array}$ & $\begin{array}{l}\text { Feed trial } \\
\text { ADG, kg }\end{array}$ & $\begin{array}{l}\text { Postweaning } \\
\text { ADG, kg }\end{array}$ & $\begin{array}{l}\text { Gain:feed } \\
\text { ratio }\end{array}$ \\
\hline 1978 & 118 & 80 & 25.9 & 0.26 & 105 & 33.5 & 54.4 & 0.20 & 0.21 & 0.127 \\
\hline 1980 & 116 & 83 & 24.4 & 0.24 & 105 & 31.5 & 56.7 & 0.25 & 0.26 & 0.141 \\
\hline 1981 & 139 & 80 & 23.8 & 0.24 & 102 & 27.8 & 53.9 & 0.25 & 0.27 & 0.125 \\
\hline 1982 & 115 & 71 & 20.9 & 0.23 & 92 & 26.5 & 54.2 & 0.25 & 0.28 & 0.118 \\
\hline Overall $\pm \mathrm{SE}$ & 952 & $76 \pm 0.3$ & $23.5 \pm 0.2$ & $0.25 \pm 0.002$ & $98 \pm 0.3$ & $29.3 \pm 0.2$ & $53.8 \pm 0.2$ & $0.23 \pm 0.002$ & $0.25 \pm 0.002$ & $0.116 \pm 0.013$ \\
\hline
\end{tabular}

growth traits in lambs. A secondary objective was to compare economic responses of different selection alternatives related to feed efficiency traits.

\section{Materials and Methods}

Animals and Management. This study evaluated preand postweaning growth and feed consumption data of Targhee lambs born from 1978 through 1984. A full description of animals and postweaning management of lambs used in this study was previously reported (Snowder and Van Vleck, 2002). Lambs were from two Targhee genetic lines: a line selected for postweaning $\mathrm{ADG}$ and a random-mated control line. Flock size for each line was approximately 130 breeding ewes per year. Each year in the selected line, four to five yearling rams were selected for postweaning ADG and exposed to 25 to 32 ewes in single-sire mating pens. In the control line, ewes were randomly exposed to one of eight randomly chosen yearling rams. A total of 952 lambs (233 from the control line and 719 from the selected line) born to a total of 397 ewes was included in this study. The lambs were sired by 56 rams in the control line and $31 \mathrm{rams}$ in the selected line. The average inbreeding coefficient for all inbred $(n=786)$ lambs and parents in the selection line and random control lines was $2.6 \%$.

Lambs were born from late March through April. At birth or shortly thereafter, lambs were given identification tags, weighed, and tails docked with an elastic band. Ewes with newborn lambs were removed from an outside lot and placed inside a covered lambing shed in a $1.5-\mathrm{m}^{2}$ pen, typically for $2 \mathrm{~d}$, before being moved to larger outside pens with other ewes and their lambs. In early May, lambs were moved with their dams to spring grazing on sagebrush-grass range. Lambs were weaned at average age of $76 \mathrm{~d}$ and weight of $23.5 \mathrm{~kg}$ (Table 1). Preweaning ADG was defined as the difference between weaning weight and birth weight divided by days of age.

An average of 136 lambs were individually performance-tested each year for postweaning ADG and feed conversion ratio (gain/feed intake) for a 14 -wk period. All available lambs from the selected line were performance-tested (approximately 103 per year). A smaller sample of lambs from the control line (approximately 33 per year) was randomly chosen shortly after birth to be performance-tested. The average age and weight $( \pm$ SD) at start of the performance test were $98 \pm 8.9 \mathrm{~d}$ and $29.3 \pm 6.0 \mathrm{~kg}$, respectively (Table 1 ). Lambs were divided by sex (ram or ewe) into separate groups and fed in open lots with partial shade for 6 wk. The first 2 -wk period was considered an adjustment period. Following the group-feeding period, lambs were fed individually for $6 \mathrm{wk}$ to measure feed efficiency traits. Individual pens were 1.25 by $2.45 \mathrm{~m}$ in size and partial shade was provided for each lamb. To reduce the effect of feeding pen during the individual feeding period, lambs were rotated every 2 wk among the feeding pens. Lambs were then returned to the group-feeding regimen for $4 \mathrm{wk}$. Body weights were measured every 2 wk. Feed intake was measured twice a week and only during the 6-wk individual feeding period.

Lambs had free access to commercial pellets that comprised $37 \%$ barley grain and $63 \%$ alfalfa on an asfed basis. Fresh water and a commercial salt and mineral mix were freely available. Lasalocid was added to the salt and mineral mix to prevent and control coccidial disease. Lambs were checked twice daily for health and proper feeding conditions.

Postweaning ADG was defined as the final body weight minus the initial body weight on test (after the 2 -wk adjustment period) divided by the total days on test (98 d), which included the group and individual feeding periods. The ADG during the individual feeding period was defined as the lamb weight at the end of the individual feeding period minus the initial lamb weight on the individual feeding period divided by total days (42 d) in the period. Total feed intake (as-fed basis), residual feed (as-fed basis), and feed conversion ratio (gain/feed) were determined only for the 6 -wk period of individual feed trial during the performance test.

Statistical Procedures. The data contained few outliers for ADG or feed intake. Values greater than four standard deviations from the sample mean were considered to be outliers. Data from $4 \%$ of the lambs $(n=40)$ were considered unreliable and were discarded. In most cases, these lambs had exceptionally low ADG and feed intake values; such lambs were considered to be sick or not adjusted to the feeding regimen. 
Residual feed intake for individuals was estimated using the GLM procedures of SAS (SAS Inst. Inc., Cary, NC). Predicted feed intake was estimated by regressing total feed intake on mid-test live body weight [(final weight - initial weight)/2 + initial weight] and on ADG during the individual feeding trial. The unadjusted means $( \pm \mathrm{SD})$ for mid-test live weight and ADG were $40.2 \pm 6.8$ and $0.233 \pm 0.032$, respectively. The model included fixed effects for year (1978 through 1984) and sex of lamb (ram, ewe), and accounted for a large portion of the total feed intake variance $\left(R^{2}=0.88\right)$. Residual feed intake was calculated by using the solutions in the equation to predict feed intake for each observation, which was then deviated from the actual feed intake for that observation. The range for residual feed intake was -23.2 to $20.4 \mathrm{~kg}$.

Genetic relationships among the lambs were generated from the Targhee pedigree file of animals born from 1960 to 1984: a total of 20,049 animals. The number of inbred animals totaled 9,407, with an average inbreeding coefficient of $3.6 \%$. Variance and covariance components were estimated using single- and two-trait models with a derivative-free REML algorithm (Graser et al., 1987) with the computer programs of Boldman et al. (1995). Convergence was considered to have been reached when the variance of the -2 log likelihoods in the simplex was less than $1 \times 10^{-6}$. After initial convergence, four restarts were performed to ensure global convergence as determined when the -2 log likelihoods did not change to the second decimal. Standard errors of heritability estimates were based on the average information matrix and the "delta" method (e.g., Dodenhoff et al., 1998).

The model for preweaning ADG included fixed effects for age of dam (1 to $9 \mathrm{yr}$ ), year, sex of lamb (ewe or ram), and type of birth and rearing (6 classifications; single born-reared, twin born-single reared, twin bornreared, triplet born-single reared, triplet born-twin reared, triplet born-reared). Random effects were additive genetic effect of the lambs, maternal genetic, and residual. Age at weaning was included as a linear covariate. The models for ADG during the postweaning period (14 wk), and during the individual feeding trial (6 wk), and for mid-test body weight were similar to that for preweaning $\mathrm{ADG}$ but did not include fixed effects for age of dam and type of birth and rearing, or the maternal genetic effect. Preliminary analyses found these fixed effects did not have a significant effect on postweaning ADG. Earlier studies have also reported that age of dam and type of birth or rearing had no effect on postweaning ADG (Basarab et al., 1987; Mousa et al., 1999) and on feed conversion ratio (Frederiksen et al., 1967). Age and initial body weight at the beginning of the performance test were considered as linear covariates for postweaning ADG.

Total feed intake, residual feed intake, and feed conversion ratio were analyzed with a model similar to that for postweaning ADG with fixed effects for year and sex, and random effects for additive genetic effects of the lamb and residual effects. Body weight and age at the beginning of the individual feed trial were linear covariates.

Body weight was included as a linear covariate to standardize the traits to a weight-constant basis. This covariate may account for some of the additive genetic variance for growth rate, intake, and feed efficiency traits (Chambers et al., 1994). Therefore, single- and two-trait animal models with and without body weight as a covariate effect were considered for feed trial ADG, postweaning ADG, feed conversion ratio, total feed intake, and residual feed intake. The effect of body weight as a covariate on the log likelihoods and estimates of variance components were examined to determine the most appropriate model.

Several selection approaches that have been previously proposed to improve feed efficiency were compared based on the expected economic improvement. Direct and indirect selection responses for ADG and against total feed intake were predicted using standard expected response equations (Falconer, 1981). Estimates of genetic and phenotypic components of variance from this study were used to parameterize the equations. The selection intensity factor was based on selection of the top $5 \%$ of rams. Responses to multitrait selection for two and three traits were also predicted (Van Vleck, 1993). The three-trait selection index included mid-test live body weight, $\mathrm{ADG}$, and total feed intake. The two-trait index included ADG and total feed intake.

Restricted multitrait indices for the same traits were also evaluated according to Kennedy et al. (1993) and Van Vleck (1993). Kennedy et al. (1993) showed that the traits used to calculate residual feed are phenotypically independent but not necessarily genetically independent. Therefore, they proposed that residual feed should be based on genotypic regression that is equivalent to a restricted selection index holding production traits (i.e., body weight and ADG) constant. Restricted indices were developed to hold the expected genetic responses for mid-test weight and ADG to zero (constant).

The economic value for lamb live body weight was estimated to be $\$ 1.63$ USD per kilogram based on a 5yr market average price for fall slaughter lambs. The expense for total feed costs associated with a largecapacity lamb-feeding system (approximately 50,000 animals per annum) could not be directly obtained from the literature or other data. Therefore, feed cost was approximated from two major lamb feedlots (personal communication); one on the West Coast and the other in the Midwest. Costs associated with a kilogram of gain in these large feedlots ranged from $\$ 1.21$ to $\$ 2.20$. An average feed-to-gain conversion ratio of 6.5 was reported by both feedlots. This feed-to-gain ratio was preferred over that reported in our study (Table 1) because of the higher percentage of grain fed in contemporary feedlot rations. The average value for costs associated with a kilogram of feed was estimated by both feedlots to be $\$ 0.20$. Total feed cost would be expected to include 
Table 2. Traits and respective economic values (EV) for selection strategies evaluated to improve the economics of postweaning feeding

\begin{tabular}{|c|c|c|c|c|c|c|}
\hline Strategy & Trait 1 & EV 1 & Trait 2 & EV 2 & Trait 3 & EV 3 \\
\hline Direct & $\mathrm{ADG}$ & 1 & & & & \\
\hline Direct & Total feed & -1 & & & & \\
\hline Direct & Gain:feed ratio & 1 & & & & \\
\hline Direct & Residual feed & 1 & & & & \\
\hline Index I & Total feed & -0.20 & $\mathrm{ADG}$ & 1.63 & Mid-test wt & 0 \\
\hline Index II & Total feed & -0.20 & $\mathrm{ADG}$ & 1.63 & & \\
\hline Restricted I & Total feed & -0.20 & $\mathrm{ADG}$ & $0^{\mathrm{a}}$ & Mid-test wt & 0 \\
\hline Restricted II & Total feed & -0.20 & $\mathrm{ADG}$ & 0 & & \\
\hline
\end{tabular}

${ }^{\text {a}}$ Restricted indices held genetic change of ADG and/or mid-test wt constant.

such expenses as feed, facilities, equipment, death loss, veterinary and health expenses, insurance, interest, shipping, commissions, and labor. Feed cost was given a negative value in the index. In the three-trait selection index, the value of lamb live weight on feed was set to zero to avoid giving it selection emphasis. The feedlot period was restricted to $42 \mathrm{~d}$ as representative of the feed intake data in this study. Typically, lambs are in a feedlot for 40 to $90 \mathrm{~d}$ dependent upon initial weight and rate of gain. The traits and economic weights associated with these selection strategies are listed in Table 2 .

To examine different scenarios in occasional price fluctuations, the economic weights for lamb live weight price and feed cost were varied. Feed costs were assumed to fluctuate $25 \%$ and set at $\$ 0.15$ for low costs and $\$ 0.20$ for high costs. Low and high lamb live weight prices were set at $\$ 1.22$ and $\$ 2.20$, respectively. The previously mentioned selection approaches were again used to compare selection economic efficiencies.

\section{Results and Discussion}

Overall means for ADG during preweaning, feed trial, and postweaning periods were similar and ranged from 0.23 to $0.25 \mathrm{~kg}$ (Table 1). Preweaning ADG (0.25 $\mathrm{kg}$ ) was similar to that reported for lambs reared on intermountain western range ( 0.23 to $0.26 \mathrm{~kg}$ for four different breeds; Bromley et al., 2001) but less than that observed in Targhee ram lambs raised on northern Californian coastal range ( $0.34 \mathrm{~kg}$; Brown et al., 1987).

Postweaning ADG $(0.25 \mathrm{~kg})$ was less than that reported for Targhee ram lambs $(\mathrm{n}=23)$ under similar conditions ( 0.27 to $0.32 \mathrm{~kg}$; Brown et al., 1987) but greater than a multibreed average reported for Rambouillet, Dorset, and Finnish Landrace ram lambs (0.21 kg; Notter et al., 1984) with ad libitum access to a high energy and protein ration for $20 \mathrm{wk}$. Although individual feeding of lambs has been shown to decrease ADG by approximately $10 \%$ when compared to group feeding over a 97-d period (Kroman et al., 1971), ADG did not differ between the group and individual feeding periods in the present study.

The unadjusted mean for final live weight was 53.8 $\mathrm{kg}$ (Table 1). Because the current slaughter weight of lambs in the United States is approximately $64 \mathrm{~kg}$, extrapolation of the results of this study to heavier lamb weights is not recommended.

The mean of the feed conversion ratio (gain/feed) for the 6-wk individual feed trial period was 0.116 , which is in agreement with the report by Vesely et al. (1970) for Rambouillet (0.093) and Romnelet (0.091) ram lambs fed a diet similar to that in the present study. Notter et al. (1984) reported feed conversion ratio values for Rambouillet (0.172), Dorset (0.161), and Finnish Landrace (0.133) rams growing in the range of 22 to 38 $\mathrm{kg}$ live weight. Brown et al. (1987) reported a range of 0.137 to 0.172 for Targhee ram lambs whose age, weight, and diet were similar to the lambs in the present study.

The phenotypic relationships of total feed intake and residual feed with mid-test body weight and ADG during the individual feeding period are depicted in Figures 1 and 2. Live weight and ADG have a positive linear relationship with total feed intake $\left(\mathrm{r}^{2}=0.76\right.$ and 0.54 , respectively). The linear relationship of body weight to total feed consumption has been previously discussed by Notter et al. (1984). Because neither of the relationships of total feed intake with mid-test weight or ADG passes through the origin, spurious correlations between these variables may exist and therefore bias conclusions related to the feed conversion ratio trait (Kronmal, 1993). The variability for total feed intake along the regression line tends to be less for live weight when compared to its relationship with ADG. As expected, residual feed has a random distribution along the zero axes for live weight and ADG $\left(\mathrm{r}^{2}=0.00\right.$ for both traits). However, residual feed estimates may be biased by underlying genetic relationships of live weight and ADG with total feed intake (Kennedy et al., 1993; Robinson, 2002).

Estimates of variance components and fractions of total variance from single-trait models are reported in Table 3 . The covariate of initial weight on test to adjust lamb performance to a constant-weight basis did not affect the estimate of additive genetic variance of the traits; however, including live weight as a covariate increased the $-2 \log$ likelihood for most traits. An exception to this was observed in the analyses of residual feed intake, where the likelihood did not change with 

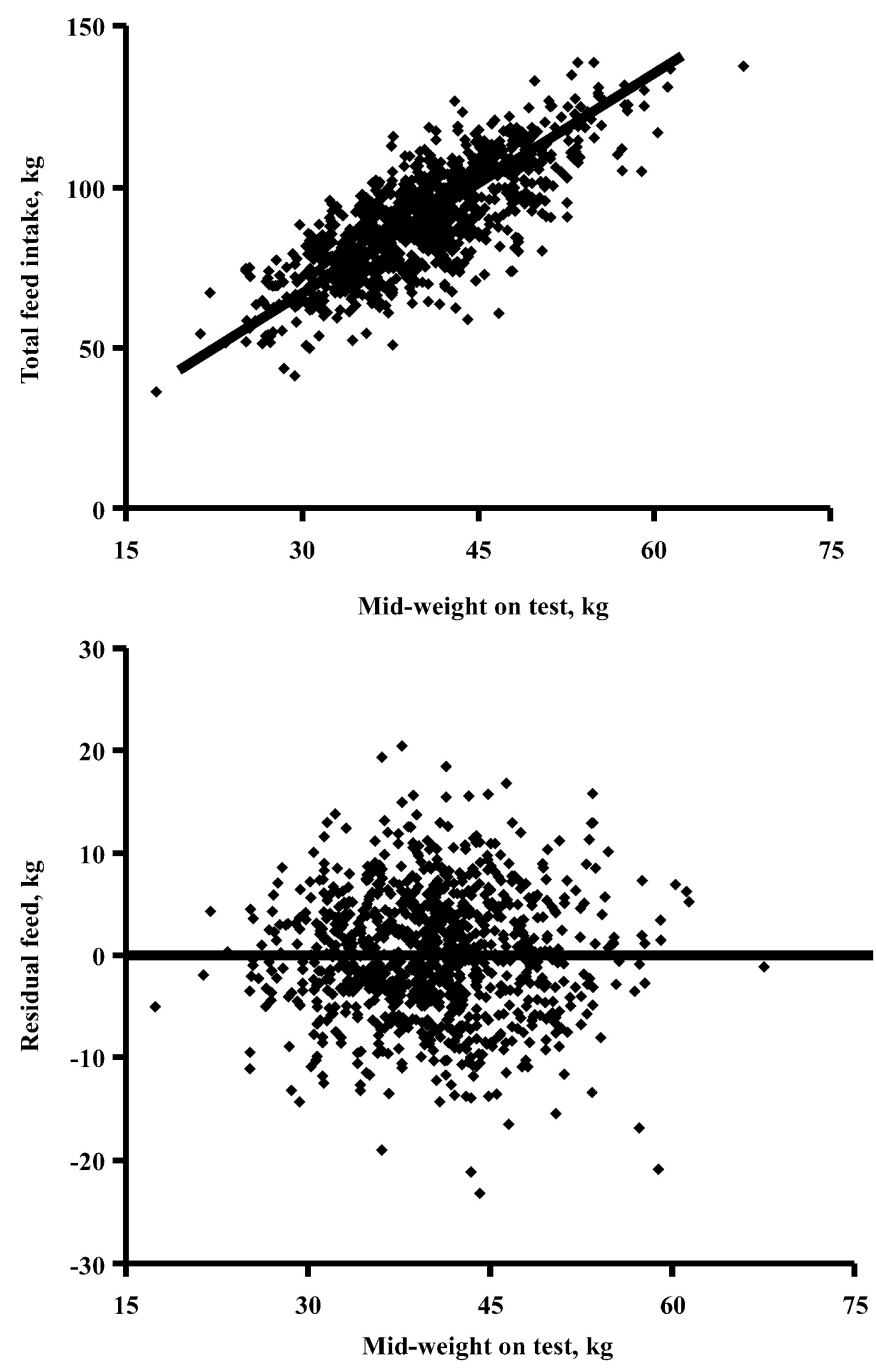

Figure 1. Relationship of lamb weight with total and residual feed intake.

or without live weight as a covariate; this was assuredly due to the preadjustment of residual feed intake for lamb live weight.

Preweaning ADG was significantly influenced by maternal genetic effects. The maternal heritability estimate for preweaning $\mathrm{ADG}$ was 0.28 , whereas the heritability estimate of direct additive genetic effects was only 0.03 . These estimates agree with previously reported estimates, indicating that the direct additive genetic variance is much smaller than maternal additive genetic variance for preweaning growth and weight traits (Al-Shorepy and Notter, 1996; Bromley et al., 2001).

Heritability estimates from the present study may differ from those of earlier studies because statistical procedures used previously for estimating heritability (half-sib correlation and intrasire regression) for preweaning growth traits may have been subject to biases from environmental adjustments (Shelton and Campbell, 1962) and did not account for the maternal genetic effects. Heritability estimates for preweaning growth rate from earlier studies have varied $(0.10$ for crossbred
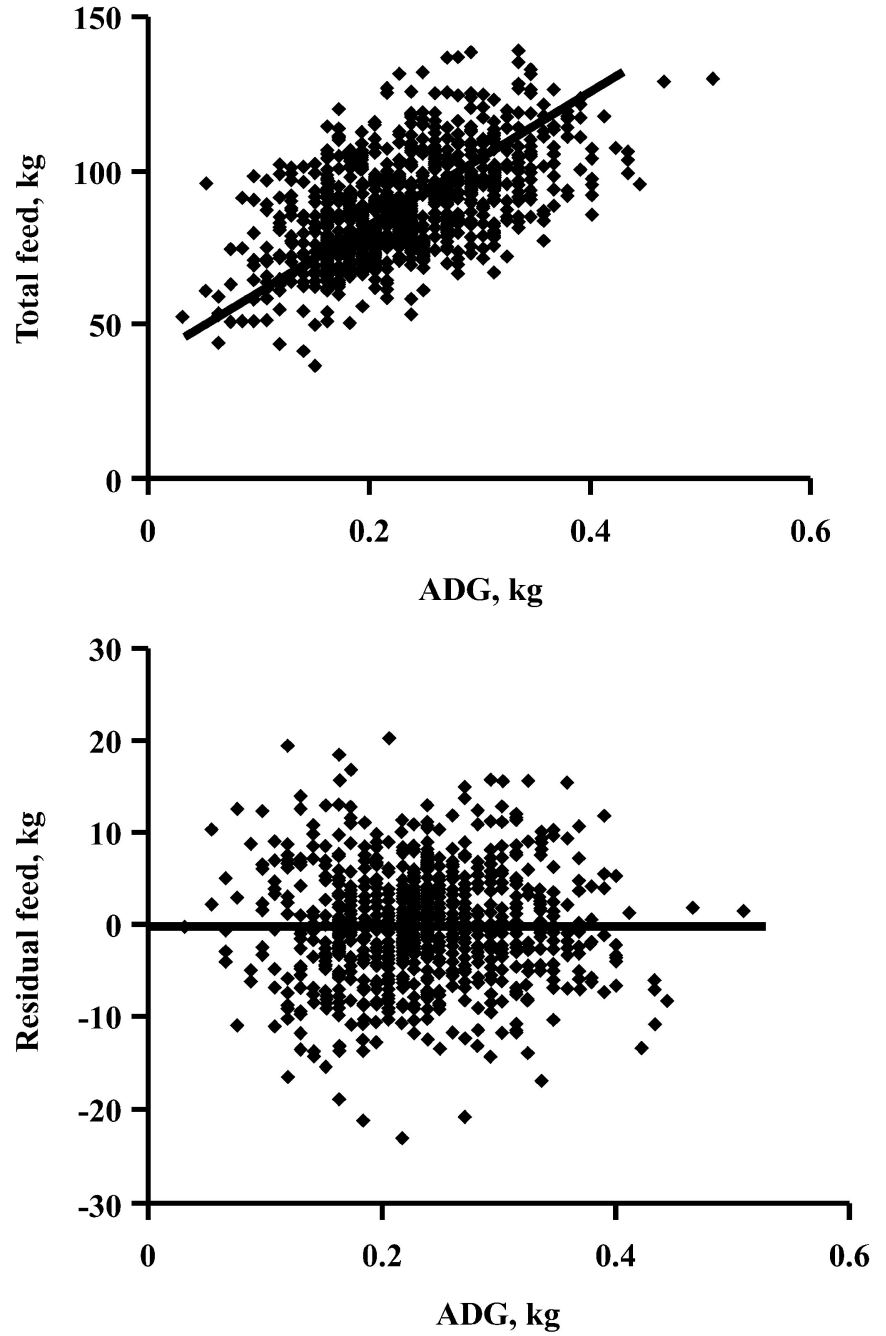

Figure 2. Relationship of lamb ADG with total and residual feed intake.

lambs weaned at $23 \mathrm{~kg}$, Harrington et al., 1962; 0.13 to 0.48 for Rambouillet lambs weaned at an average weight of $29.5 \mathrm{~kg}$, Shelton and Campbell, 1962; 0.22 for Hampshire lambs weaned at $23 \mathrm{~kg}$, Vogt et al., 1967). Similarly, an extensive review of genetic parameter estimates (Fogarty, 1995) reported a wide range of heritability estimates for weaning weight (0.02 to 0.45).

The heritability estimate for postweaning ADG was high (0.39). Previously reported heritability estimates for postweaning $\mathrm{ADG}$ ranged from 0.21 (Vesely et al., 1970; Mousa et al., 1999) to 0.38 (Harrington et al., 1962). The heritability estimate for ADG during the 6wk individual feeding period (0.25) was in agreement with 0.27 reported by Leymaster et al. (2002) for ADG of composite lambs during a 7-wk postweaning period; however, Francois et al. (2002) reported a higher estimate of 0.43 for the French INRA401 breed. The higher heritability estimate for ADG during the entire 14-wk postweaning period compared to the 6 -wk feed trial period is associated with the increased duration of the feeding period (Harrington et al., 1962) and the age of 
Selection approaches for improving feed efficiency

Table 3. Estimates of variance components and fractions of total variance from single trait models ${ }^{\mathrm{a}}$

\begin{tabular}{lccccc}
\hline \hline Trait & $\sigma_{\mathrm{a}}^{2}$ & $\sigma_{\mathrm{e}}^{2}$ & $\sigma_{\mathrm{p}}^{2}$ & $\mathrm{~h}^{2}$ & $\mathrm{e}^{2}$ \\
\hline Preweaning ADG, kg & 0.00007 & 0.00163 & 0.0024 & $0.03 \pm 0.04$ & $0.69 \pm 0.05$ \\
Postweaning ADG, kg & 0.00050 & 0.00079 & 0.0013 & $0.39 \pm 0.07$ & $0.61 \pm 0.07$ \\
Feed trial ADG, kg & 0.00068 & 0.00211 & 0.0028 & $0.25 \pm 0.06$ & $0.75 \pm 0.06$ \\
Mid-test body wt, kg & 0.61 & 2.16 & 2.78 & $0.22 \pm 0.06$ & $0.78 \pm 0.06$ \\
Gain:feed ratio & 0.00006 & 0.00054 & 0.0006 & $0.10 \pm 0.05$ & $0.90 \pm 0.05$ \\
Total feed intake, kg & 32.8 & 51.2 & 84.0 & $0.39 \pm 0.07$ & $0.61 \pm 0.07$ \\
Residual feed intake, kg & 9.8 & 28.0 & 37.8 & $0.26 \pm 0.07$ & $0.74 \pm 0.07$ \\
\hline
\end{tabular}

${ }^{\mathrm{a}} \sigma_{\mathrm{a}}^{2}=$ additive genetic variance; $\sigma_{\mathrm{e}}^{2}=$ residual variance; $\sigma_{\mathrm{p}}^{2}=$ phenotypic variance; $\mathrm{h}^{2}=$ heritability estimate; $\mathrm{e}^{2}=$ fraction of phenotypic variance due to environmental effects.

${ }^{\mathrm{b}}$ Maternal additive variance $=0.00066$, and maternal heritability estimate $=0.28 \pm 0.08$.

the lambs (Olson et al., 1976; Nsholm and Danell, 1996). Previous studies have reported that genetic correlations for gain are generally positive and much larger than environmental correlations as time on feed increases, indicating genetic influences persist but environmental influences do not as time on feed increases (lambs, Snowder and Van Vleck, 2002; cattle, Swiger, 1961, and Koch et al., 1982). The heritability estimate for mid-test weight was moderate (0.22) and agrees with the review of Fogarty (1995) of genetic parameters for postweaning weights.

The heritability estimate for the feed conversion ratio was low (0.10) and in agreement with estimates of 0.06 for Rambouillet and 0.18 for Romnelet ram lambs reported by Vesely et al. (1970). Estimates for other species have been low to moderate $(0.12$ for goats, Khan and Singh, 1995; 0.16 and 0.26 for beef cattle, Fan et al., 1995 and Bishop et al., 1991, respectively; 0.12 for swine, Jungst et al., 1981; and, 0.27 for mice, Sutherland et al., 1970).

The heritability estimate for total feed intake was high (0.39) and agrees with an estimate derived from French sheep (0.43, Francois et al., 2002). Lower estimates for daily feed intake have been reported for lambs (0.25, Leymaster et al., 2002) and swine (0.22, Jungst et al., 1981). Heritability estimates for feed intake in beef cattle have been high (0.40, Scholtz et al., 1998; and 0.39, Arthur et al., 2001a).

The heritability estimate for residual feed intake was moderate $(0.26)$. This was attributed to decreases in the additive and phenotypic variances (70 and 55\%, respectively) when compared to total feed intake. This estimate agrees with values reported for sheep $(0.30$, Francois et al., 2002) and is similar to that reported in other species ( 0.28 and 0.43 . for beef cattle, Koch et al., 1963 and Arthur et al., 2001b, respectively; 0.28 to 0.36 in dairy bulls, Jensen et al., 1992; 0.33 in growing boars, Mrode and Kennedy, 1993; and 0.27 in mice, Neilsen et al., 1997).

Environmental effects had a large influence on all traits. The estimated fraction of phenotypic variance due to environmental effects ranged from 0.61 to 0.78 for all traits except feed conversion ratio (0.90).
Variance components estimates from the bivariate analyses were similar to those from the single-trait model for all pairs of traits and are not reported. Estimates of genetic correlations (Table 4) among pre-, postweaning, and feed trial ADG were high, ranging from 0.97 to 0.99 . Overall growth rate may be improved by selection on ADG for any or all of the periods of measurements. The maternal genetic effect for preweaning ADG had negative correlations with other ADG traits but these were near zero. Negative genetic relationships between maternal effects and growth rates have been previously reported in beef cattle (Deese and Koger, 1967; Vesely and Robison, 1971).

Growth rates during the postweaning and feed trial period had large and positive estimates of genetic correlations with feed trial mid-test weight, total feed intake, and feed conversion ratio. Selection for growth rate or live weight would be expected to increase feed intake as well as to improve feed conversion ratio (Turner, 1959; Sutherland, 1965). These estimates agree with previous estimates of genetic correlation for postweaning $\mathrm{ADG}$ with feed conversion ratio (feed/gain) of -0.43 for Rambouillet and -1.00 for Romnelet (Vesely et al., 1970) and 0.80 for postweaning ADG with total feed intake for crossbred lambs (Leymaster et al., 2002). Large standards errors for estimates of genetic correlations associated with preweaning ADG were assumed to be related to the near zero additive variance for preweaning ADG. From a large study of Angus beef cattle (Arthur et al., 2001a), estimates of genetic correlations of postweaning ADG with mid-test weight and feed intake were 0.53 and 0.54 , respectively. Fan et al. (1995) reported a wide range of estimates of genetic correlations for Hereford and Angus cattle ADG and feed conversion ratio ( 0.42 vs. 0.73$)$. Arthur et al. (2001b) reported a genetic correlation of -0.10 between ADG and residual feed for Charolais bulls. For mice, realized genetic correlations of postweaning ADG with feed intake and feed conversion ratio after 22 generations of selection were reported to be large ( 0.88 and 0.91 ; Sutherland et al., 1970).

Residual feed was positively (unfavorably) correlated genetically with all traits except with the maternal ef- 
Table 4. Estimates of genetic correlations among lamb growth and feed efficiency traits

\begin{tabular}{|c|c|c|c|c|c|c|c|}
\hline Trait & $\begin{array}{c}\text { Preweaning } \\
\mathrm{ADG}_{\mathrm{mat}}\end{array}$ & $\begin{array}{c}\text { Postweaning } \\
\text { ADG }\end{array}$ & $\begin{array}{l}\text { Feed trial } \\
\text { ADG }\end{array}$ & $\begin{array}{l}\text { Mid-test } \\
\text { body wt }\end{array}$ & $\begin{array}{l}\text { Total feed } \\
\text { intake }\end{array}$ & $\begin{array}{l}\text { Residual } \\
\text { feed }\end{array}$ & $\begin{array}{l}\text { Gain:feed } \\
\text { ratio }\end{array}$ \\
\hline Preweaning ADG, kg & $-0.04 \pm 0.686$ & $0.98 \pm 0.627$ & $0.99 \pm 0.506$ & $0.01 \pm 0.000$ & $0.90 \pm 0.645$ & $0.86 \pm 0.615$ & $0.92 \pm 0.748$ \\
\hline Postweaning ADG, kg & - & - & $0.97 \pm 0.050$ & $0.93 \pm 0.094$ & $0.92 \pm 0.066$ & $0.33 \pm 0.166$ & $0.99 \pm 0.213$ \\
\hline Feed trial ADG, kg & - & - & - & $0.97 \pm 0.053$ & $0.84 \pm 0.072$ & $0.29 \pm 0.201$ & $0.85 \pm 0.156$ \\
\hline Mid-test body wt, kg & - & - & - & - & $0.71 \pm 0.114$ & 0.0 & $0.79 \pm 0.213$ \\
\hline
\end{tabular}

${ }^{\text {aPreweaning }} \mathrm{ADG}_{\text {mat }}=$ maternal direct genetic effect of the lamb's dam.

fect for preweaning ADG. Residual and total feed were highly correlated. Francois et al. (2002) reported a smaller genetic correlation between residual and total feed $\left(r_{g}=0.59\right)$. For beef cattle, this genetic relationship has been reported to be similar $\left(\mathrm{r}_{\mathrm{g}}=0.69\right.$, Arthur et al., 2001a). The estimates of genetic correlations of residual feed with weight and $\mathrm{ADG}$, traits used in derivation of residual feed, were small ( 0.0 and 0.29 , respectively). Selection to decrease residual feed would be expected to result in a negative effect on traits related to growth rate and weight. For beef cattle, Arthur et al. (2001a) concluded that selection against residual feed would not change ADG $\left(r_{g}=-0.04\right)$ but would increase $400-d$ calf weight $\left(r_{\mathrm{g}}=-0.26\right)$.

Estimates of environmental correlations (Table 5) of preweaning ADG with postweaning and feed trial ADG were negative but near zero. The estimate of the environmental correlation between growth rates for the postweaning growth period that included group and individual feeding with $\mathrm{ADG}$ for the individual feeding period was less than expected $\left(\mathrm{r}_{\mathrm{e}}=0.38\right)$ as was the estimate of the environmental correlation between midtest weight and postweaning ADG $\left(\mathrm{r}_{\mathrm{e}}=0.22\right)$. Feed intake was environmentally correlated with measures of postweaning growth and weight. The estimate of the environmental correlation between total and residual feed intake was large and positive. Feed conversion ratio was the only trait with a significant favorable environmental correlation with residual feed intake $\left(\mathrm{r}_{\mathrm{e}}\right.$ $=-0.32$ ).

Predicted economic responses per generation for the selection strategies were highly variable (Table 6). Gain in lamb weight generally had the largest influence on expected economic response. The unrestricted selection indices including two and three traits had the greatest expected economic gains per generation $(\$ 0.98$ and $\$ 1.05$, respectively). The expected economic improvement from direct selection for ADG was $\$ 0.88,16 \%$ less than that expected with the three-trait selection index. The least expected economic improvement was for selection against residual feed $(\$ 0.12)$. Three expected economic responses with the restricted indices were positive and 50 to $105 \%$ greater than expected from selection against residual feed but considerably less than with the unrestricted indexes. Selection for feed conversion ratio would result in expected response similar to responses for the restricted indices. An economic loss would be expected from selection to reduce total feed intake.

When economic values were varied between low and high estimates (Table 7), economic improvement varied among selection criteria. Generally, the largest economic improvements were observed with selection indices. However, direct selection against residual or total feed was favored for low lamb prices with high feed costs. When the live lamb price was high, selection criteria related to lamb weight gain had larger economic improvements compared to selection criteria for feed. The economic improvement with restricted indices was always positive and only influenced by feed costs because live weight and/or gain were held constant. Direct selection for ADG also resulted in positive economic improvements for all economic scenarios. Because ADG is perhaps the most practical and easiest trait to measure, breeders desiring to improve economic returns and feed efficiency should consider selecting for ADG.

These results are in agreement with previous reports. The superiority of index selection over single-trait selec-

Table 5. Estimates of environmental correlations among lamb growth and feed efficiency traits

\begin{tabular}{|c|c|c|c|c|c|c|}
\hline Trait & Postweaning & Feed trial & $\begin{array}{l}\text { Mid-test } \\
\text { body wt }\end{array}$ & $\begin{array}{l}\text { Total feed } \\
\text { intake }\end{array}$ & $\begin{array}{l}\text { Residual feed } \\
\text { intake }\end{array}$ & $\begin{array}{l}\text { Gain:feed } \\
\text { ratio }\end{array}$ \\
\hline Preweaning ADG, kg & $-0.15 \pm 0.064$ & $-0.02 \pm 0.054$ & $0.90 \pm 0.017$ & $-0.08 \pm 0.063$ & $-0.06 \pm 0.055$ & $-0.04 \pm 0.052$ \\
\hline Feed trial ADG, kg & - & - & $0.58 \pm 0.032$ & $0.64 \pm 0.034$ & $-0.14 \pm 0.058$ & $0.48 \pm 0.037$ \\
\hline Mid-test body wt, kg & - & - & - & $0.49 \pm 0.044$ & 0.0 & $0.21 \pm 0.061$ \\
\hline Total feed, kg & - & - & - & - & $0.64 \pm 0.036$ & $0.08 \pm 0.053$ \\
\hline
\end{tabular}


Table 6. Expected direct and correlated genetic responses and total economic gain or loss per generation with different selection strategies ${ }^{\mathrm{a}}$

\begin{tabular}{lccc}
\hline \hline Method & $\begin{array}{c}\text { Total gain, } \\
\mathrm{kg}\end{array}$ & $\begin{array}{c}\text { Feed intake, } \\
\mathrm{kg}\end{array}$ & $\begin{array}{c}\text { Total economic } \\
\text { change, } \$ \text { US }\end{array}$ \\
\hline Direct for ADG & 1.15 & 4.96 & 0.88 \\
Direct against feed intake & -1.20 & -7.37 & -0.49 \\
Direct for feed efficiency & 0.60 & 2.89 & 0.40 \\
Direct against residual feed & -0.33 & -3.30 & 0.12 \\
Index I & 1.09 & 3.65 & 1.05 \\
Index II & 1.08 & -3.88 & 0.98 \\
Restricted I & 0 & -1.64 & 0.33 \\
Restricted II & 0 & -2.27 & 0.45 \\
\hline
\end{tabular}

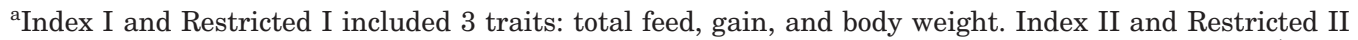
did not include body weight. Restricted indices held gain and body weight constant. Economic values: \$1.63/ $\mathrm{kg}$ of gain; $\$ 0.20 / \mathrm{kg}$ feed.

tion for economically important traits was described by Hazel and Lush (1942). The reduction in efficiency of selection for a trait defined as a ratio compared to efficiency of a linear selection index was described by Gunsett (1984). Greater expected economic response from multitrait restricted indices compared with response from direct selection against residual feed was suggested by Kennedy et al. (1993). The greater expected economic improvement from direct selection for ADG compared to most other selection approaches associated with efficiency was alluded to by Cameron (1998).

Selection for preweaning gain might result in an expected response similar to that of direct selection for postweaning gain based on the large genetic correlation $\left(\mathrm{r}^{2}=0.98\right)$. Selection for preweaning gain will indirectly improve efficiency of gain but not residual feed. However, the small heritability estimate for the direct additive effect on preweaning gain will result in a much lower expected selection response compared to that from direct selection for postweaning gain.

Other factors related to predicted economic responses to selection include associated costs of collecting data for traits of interest and measurement errors of the traits. Whether the costs of improving efficiency of gain by selection can be recovered within a desired short- or long-term selection period should be determined. At present, facilities, equipment, and labor needed to measure individual feed intake are generally considered cost prohibitive. For example, in this study, the expected difference in economic responses for direct selection for $\mathrm{ADG}$ and the selection index with three traits ( $\mathrm{ADG}$, weight, and feed intake) is only $\$ 0.17$ less per lamb per generation. The costs of measuring feed intake must be balanced against a relatively low return.

Another consideration is that although selection for $\mathrm{ADG}$ during the postweaning period is the most practical approach for improving efficiency, other traits not measured in this study may indirectly respond to selection in positive or negative ways. Selection for rate of gain will generally increase mature size of ewes (Brown et al., 1987), cows (Brinks et al., 1964), and rats (Sutherland et al., 1970). For sheep, increasing ewe mature size has been shown to improve milk production, result in a leaner carcass at a given slaughter weight (Brown et al., 1987), and improve ewe reproductive rate (Ercanbrack and Knight, 1998). The average estimate of genetic correlation between ewe mature size and reproductive rate (number of lambs weaned per ewe exposed) is 0.31 (Fogarty, 1995). An increase in ewe mature size, however, may also increase production costs due to the

Table 7. Total economic gain or loss (\$US) per animal per generation with low and high economic values for lamb weight and feed costs under different selection strategies ${ }^{\mathrm{ab}}$

\begin{tabular}{lrrrr}
\hline \hline Method & LL/LF & LL/HF & HL/LF & HL/HF \\
\hline Direct for ADG & 0.66 & 0.16 & 1.79 & 1.29 \\
Direct against feed intake & -0.36 & 0.38 & -1.53 & -0.80 \\
Direct for feed efficiency & 0.30 & 0.01 & 0.89 & 0.60 \\
Direct against residual feed & 0.09 & 0.42 & -0.23 & 0.60 \\
Index I & 0.78 & -0.07 & 1.94 & 1.49 \\
Index II & 0.74 & -0.06 & 1.88 & 1.41 \\
Restricted I & 0.41 & 0.25 & 0.41 & 0.25 \\
Restricted II & 0.56 & 0.34 & 0.56 & 0.34 \\
\hline
\end{tabular}

${ }^{\mathrm{a}}$ Economic values: $\mathrm{LL}=\$ 1.22 \mathrm{~kg}$ lamb wt, $\mathrm{HL}=\$ 2.20 \mathrm{~kg}$ lamb wt, $\mathrm{LF}=\$ 0.15$ feed costs, $\mathrm{HF}=\$ 0.25$ feed costs.

${ }^{\mathrm{b}}$ Index I and Restricted I included three traits: total feed, gain, and body weight. Index II and Restricted II did not include body weight. Restricted indices held gain and body weight constant. 
increased feed needed to maintain the ewe. In environments with limiting feed resources, a larger ewe may be undesirable. Mature size may have a positive relationship with biological efficiency, but it is usually small (e.g., a $25 \%$ increase in mature weight would result in only a $3.8 \%$ increase in biological efficiency; Thompson and Barlow, 1986), and thus, biological efficiency would not be greatly affected. However, if reproductive rate increases with the size of the ewe, biological efficiency would also improve.

In a segmented industry, such as the U.S. sheep industry, which is divided into producer, feeder, and packer entities, postweaning gain and feed efficiency traits for lambs are of interest only to the feeding industry. Commercial lamb producers are unlikely to place heavy selection emphasis on postweaning gain when reproductive rate is far more economically important to them. This attitude would change if feeders were willing to pay an incentive for faster growing or more efficient lambs. Until then, the pure breed industry that has traditionally selected animals for conformation, size, and growth, especially terminal meat sire breeds, will likely be the only segment of the industry that focuses on improving rate of gain.

The cost of comparing animals for feed efficiency has been perhaps the greatest handicap for genetic improvement. The number of animals entered into a feed efficiency trial may be reduced if an efficacious screening test were available. For beef cattle, it has been suggested that IGF-I, which is phenotypically associated with feed conversion efficiency and growth rate (Davis et al., 1995), can be used to economically screen beef cattle put on test (Wood et al., 2002). Such a twostage selection program may be practical for sheeptesting stations.

Selection for improved gain would be expected to result in significant biological changes in sheep. Three studies have investigated the biology of the animals used in this study by comparing selected and random bred control lines. Selection for rate of gain resulted in higher levels of plasma growth hormone and thyrotropin levels (Dodson et al., 1983); greater tissue oxygen consumption rates (Rompala et al., 1987); and a 4\% decrease in metabolizable energy for maintenance, $7.8 \%$ increase in fasting heat production, and $13 \%$ heavier ruminal weight (Rompala et al., 1991). The lower maintenance requirement for metabolizable energy would be of economic importance.

\section{Implications}

This study adds to the limited information on the genetics of efficiency of gain in sheep. One of the first heritability estimates for residual feed for gain in sheep was reported: the genetic correlation of residual feed with other measures of growth and feed intake were described. Most importantly, these estimates of genetic parameters were used to compare various selection strategies to improve efficiency of gain. These compari- sons revealed that the economic advantage to collecting feed intake to improve feed efficiency of postweaning gain is small and may not be justified when the cost of measurement of feed intake is considered. Direct selection for ADG is the more practical alternative compared with other selection strategies that include some measure of feed intake.

\section{Literature Cited}

Al-Shorepy, S. A., and D. R. Notter. 1996. Genetic variation and covariation for ewe reproduction, lamb growth, and lamb scrotal circumference in a fall-lambing sheep flock. J. Anim. Sci. 74:1490-1498.

Arthur, P. F., J. A. Archer, D. J. Johnston, R. M. Herd, E. C. Richardson, and P. F. Parnell. 2001a. Genetic and phenotypic variance and covariance components for feed intake, feed efficiency and other postweaning traits in Angus cattle. J. Anim. Sci. 79:2805-2811.

Arthur, P. F., G. Renand, and D. Krauss. 2001b. Genetic and phenotypic relationships among different measures of growth and feed efficiency in young Charolais bulls. Livest. Prod. Sci. 68:131-139.

Basarab, J. A., J. N. B. Shrestha, and R. J. Parker. 1987. Effects of birth type, age of dam, entry weight and prestation gain on test station results of ram lambs. Can. J. Anim. Sci. 67:371-379.

Bishop, M. D., M. E. Davis, W. R. Harvey, G. R. Wilson, and B. D. VanStaven. 1991. Divergent selection for postweaning feed conversion in Angus beef cattle: I. Mean comparisons. J. Anim. Sci. 69:4348-4359.

Boldman, K. G., L. A. Kriese, L. D. Van Vleck, C. P. Van Tassell, and S. D. Kachman. 1995. A Manual for Use of MTDFREML. A set of programs to obtain estimates of variances and covariances. USDA, ARS, Clay Center, NE.

Bromley, C. M., L. D. Van Vleck, and G. D. Snowder. 2001. Genetic correlations for litter weight weaned with growth, prolificacy, and wool traits in Columbia, Polypay, Rambouillet, and Targhee sheep. J. Anim. Sci. 79:339-346.

Brown, D. L., M. R. Dally, M. R. Schwartz, and G. E. Bradford. 1987. Feed efficiency, growth rates, body composition, milk production and milk composition of Targhee sheep selected for increased weaning weight. J. Anim. Sci. 65:692-698.

Cameron, N. D. 1998. Across species comparisons in selection for efficiency. Proc. 6th World Cong. Gen. Appl. Livest. Prod., Armidale, Australia 25:73-80.

Chambers, J. R., L. Wang, and I. McMillian. 1994. Genetic variation of broiler feed consumption and efficiency corrected for differences in test body weights. Poult. Sci. 73:1196-1203.

Davis, M. E., M. D. Bishop, N. H. Park, and R. C. M. Simmen. 1995. Divergent selection for blood serum insulin-like growth factor I concentration in beef cattle: I. Nongenetic effects. J. Anim. Sci. 73:1927-1932.

Deese, R. E., and M. Koger. 1967. Maternal effects on pre-weaning growth rate in cattle. J. Anim. Sci. 26:250-253.

Dodenhoff, J., L. D. Van Vleck, S. D. Kachman, and R. M. Koch. 1998. Parameter estimates for direct, maternal and grandmaternal genetic effects for birth weight and weaning weight in Hereford cattle. J. Anim. Sci. 76:2521-2527.

Dodson, M. V., S. L. Davis, D. L. Ohlson, and S. K. Ercanbrack. 1983. Temporal patterns of growth hormone, prolactin and thyrotropin secretion in Targhee rams selected for rate and efficiency of gain. J. Anim. Sci. 57:338-342.

Eisen, E. J. 1977. Restricted selection index: An approach to selecting for feed efficiency. J. Anim. Sci. 44:958-972.

Ercanbrack, S. K., and A. D. Knight. 1998. Responses to various selection protocols for lamb production in Rambouillet, Targhee, Columbia, and Polypay sheep. J. Anim. Sci. 76:1311-1325.

Falconer, D. S. 1981. Selection: I. The response and its prediction. Pages 170-187 in Introduction to Quantitative Genetics. 2nd ed. Longman House, Essex, U.K. 
Fan, L. Q., D. R. C. Bailey, and N. H. Shannon. 1995. Genetic parameter estimation of postweaning gain, feed intake, and feed efficiency for Hereford and Angus bulls fed two different diets. J. Anim. Sci. 73:365-372.

Fogarty, N. M. 1995. Genetic parameters for live weight, fat and muscle measurements, wool production and reproduction in sheep: A review. Anim. Breed. 63:101-143. (Abstr.)

Francois, D., D. Bibe, J. B. Brunel, J. L. Weisbecker, and E. Ricard. 2002. Genetic parameters of feeding traits in meat sheep. Pages 233-236 in Vol. 31, Proc. 7th World Congress Gen. Appl. Livest. Prod., Montpellier, France.

Frederiksen, K. R., D. A. Price, and R. L. Blackwell. 1967. Environmental factors affecting rate and efficiency of gain and other traits in Rambouillet lambs. J. Anim. Sci. 26:667-673.

Graser, H. U., S. P. Smith, and B. Tier. 1987. A derivative-free approach for estimating variance components in animal models by restricted maximum likelihood. J. Anim. Sci. 64:1362-1370.

Gunsett, F. C. 1984. Linear index selection to improve traits defined as a ratio. J. Anim. Sci. 59:1185-1193.

Harrington, R. B., D. G. Brothers, and J. V. Whiteman. 1962. Heritability of gain of lambs measured at different times and by different methods. J. Anim. Sci. 21:78-81.

Hazel, L. N., and J. L. Lush. 1942. The efficiency of three methods of selection. J. Hered. 33: 393-399.

Khan, B. U., and S. K. Singh. 1995. Genetics of feed conversion in Barbari goats. Small Rumin. Res. 15:283-285.

Kennedy, B. W., J. H. J. van der Werf, and T. H. E. Meuwissen. 1993. Genetic and statistical properties of residual feed intake. J. Anim. Sci. 71:3239-3250.

Koch, R. M., L. A. Swiger, D. Chambers, and K. E. Gregory. 1963. Efficiency of feed use in beef cattle. J. Anim. Sci. 22:486-494.

Koch, R. M., L. V. Cundiff, and K. E. Gregory. 1982. Influence of postweaning gain interval on estimates of heritability and genetic correlations. J. Anim. Sci. 55:1301-1318.

Kroman, R. P., M. D. Finkner, and J. E. Sharp. 1971. Group feeding vs. individual feeding of lambs. J. Anim. Sci. 32:549-553.

Kronmal, R. A. 1993. Spurious correlation and the fallacy of the ratio standard revisited. J. Royal Stat. Soc. 156:379-392.

Jensen, J., I. L. Mao, B. Bech Andersen, and P. Madsen. 1992. Phenotypic and genetic relationships between residual energy intake and growth, feed intake, and carcass traits of young bulls. J. Anim. Sci. 70:386-395.

Jungst, S. B., L. L. Christian, and D. L. Kuhlers, 1981. Response to selection for feed efficiency in individually fed Yorkshire boars. J. Anim. Sci. 53:323-331.

Leymaster, K. A., K. M. Cammack, M. K. Nielsen, and T. G. Jenkins. 2002. Estimates of genetic parameters for daily gain, feed intake, and behavior traits in ram lambs of a composite population. Proc. 7th World Cong. Genet. Appl. Livest. Prod., Montpelier, France.

Mousa, E., L. D. Van Vleck, and K. A. Leymaster. 1999. Genetic parameters for growth traits for a composite terminal sire breed of sheep. J. Anim. Sci. 77:1659-1665.

Mrode, R. A., and B. W. Kennedy. 1993. Genetic variation in measures of food efficiency in pigs and their genetic relationships with growth rate and backfat. Anim. Prod. 56:225-232.

Nsholm, A., and O. Danell. 1996. Genetic relationship of lamb weight, maternal ability, and mature ewe weight in Swedish finewool sheep. J. Anim. Sci. 74:329-339.

Neilsen, M. K., L. D. Jones, B. A. Freking, and J. A. DeShazer. 1997. Divergent selection for heat loss in mice: I. Selection applied and direct response through fifteen generations. J. Anim. Sci. 75:1461-1468.

Notter, D. R., C. L. Ferrell, and R. A. Field. 1984. Effects of breed and intake on growth and feed efficiency in ram lambs. J. Anim. Sci. 58:560-576.

Olson, L. W., G. E. Dickerson, and H. A. Glimp. 1976. Selection criteria for intensive market lamb production: Growth traits. J. Anim. Sci. 43:78-89.

Robinson, D. L. 2002. Bias in multiple regression with example from feed efficiency. 7th World Cong. Genet. Appl. Livest. Prod., Montpellier, France.

Rompala, R. E., D. E. Johnson, W. V. Rumpler, H. W. Phetteplace, and C. F. Parker. 1987. Level of alimentation and line of breeding on oxygen uptake by ovine jejunal mucosa. Am. J. Physiol. 252:R398-401.

Rompala, R. E., D. E. Johnson, W. V. Rumpler, H. W. Phetteplace, S. M. Specht, and C. F. Parker. 1991. Energy utilization and organ mass of Targhee sheep selected for rate and efficiency of gain and receiving high and low planes of nutrition. J. Anim. Sci. 69:1760-1765.

Scholtz, M. M., Y. Jrgens, L. Bergh, J. van der Westhuizen, and D. J. Bosman. 1998. The importance of feed efficiency in the selection of beef cattle in South Africa. Proc. 5th World Cong. Genet. Appl. Livest. Prod., Armidale, Australia 25:89-92.

Shelton, M., and F. Campbell. 1962. Influence of environmental adjustments on heritability of weaning weight of range Rambouillet lambs. J. Anim. Sci. 21:91-94.

Snowder, G. D., and L. D. Van Vleck. 2002. Effect of duration of performance test on variance component estimates for lamb growth rate. J. Anim. Sci. 80:2078-2084.

Sutherland, T. M., P. E. Biondini, L. H. Haverland, D. Pettus, and W. B. Owen. 1970. Selection for rate of gain, appetite and efficiency of feed utilization in mice. J. Anim. Sci. 31:1049-1057.

Sutherland, T. M. 1965. The correlation between feed efficiency and rate of gain, a ratio and its denominator. Biometrics 21:739-749.

Swiger, L. A. 1961. Genetic and environmental influences on gain of beef cattle during various periods of life. J. Anim. Sci. $20: 183-188$.

Thompson, J. M., and R. Barlow. 1986. The relationship between feeding and growth parameters and biological efficiency in cattle and sheep. Proc. 3rd World Cong. Genet. Appl. Livest. Prod. Lincoln, Nebraska. XI:271-282.

Turner, H. N. 1959. Ratios as criteria for selection in animal or plant breeding with particular reference to efficiency for food conversion in sheep. Aust. J. Agric. Res. 10:565-580.

Van Vleck, L. D. 1993. Selection with more than one trait measured. Pages 151-170 in Selection Index and Introduction to Mixed Model Methods. CRC Press, Ann Arbor, MI.

Vesely, J. A., H. F. Peters, S. B. Slen, and O. W. Robison. 1970. Heritabilities and genetic correlations in growth and wool traits on Rambouillet and Romnelet sheep. J. Anim. Sci. 30:174-181.

Vesely, J. A., and O. W. Robinson. 1971. Genetic and maternal effects of pre-weaning growth and type score in beef calves. J. Anim. Sci. 32:825.

Vogt, D. W., R. C. Carter, and W. H. McClure. 1967. Genetic and phenotypic parameter estimates involving economically important traits in sheep. J. Anim. Sci. 26:1232-1238.

Wood, B. J., A. A. Archer, and J. H. J. van der Werf. 2002. Genetic and economic evaluation of IGF-1 as an indirect selection criterion in beef cattle. Pages 541-544 in Vol. 29, Proc. 7th World Cong. Gen. App. Livest. Prod. Montepellier, France. 